\title{
Toxoplasmic encephalitis during mycophenolate mofetil immunotherapy of neuromuscular disease
}

\section{OPEN}

Danilo R. Bernardo, Jr., MD

Nizar Chahin, MD

Correspondence to

Dr. Bernardo:

drbernardoj@gmail.com

ABSTRACT

Objective: To show that immunotherapy with medications such mycophenolate mofetil (MMF) can cause serious complications in patients with neuromuscular disorders.

Methods: Two patients with neuromuscular disorders on immunotherapy with long-term MMF who developed toxoplasmic encephalitis (TE) were included in this case series.

Results: One patient with myasthenia gravis and one patient with inflammatory myopathy on immunotherapy with long-term MMF developed severe TE. Diagnosis was based on clinical presentation, MRI brain imaging characteristics, and CSF PCR positivity for Toxoplasma gondii. Both patients were treated with pyrimethamine, sulfadiazine, and leucovorin for 2 months without clinical improvement, and both died.

Conclusions: Immunotherapy with medications such as MMF can cause devastating TE in non-HIV patients with neuromuscular disorders. Early consideration and recognition of this complication is important to possibly prevent unfavorable outcomes. The utility of screening and prophylaxis against toxoplasmosis in individuals with neuroimmunologic disorders and other autoimmune disorders who receive immunosuppressive therapy requires future study. Neurol Neuroimmunol Neuroinflamm 2015;2:e63; doi: 10.1212/NXI.0000000000000063

\section{GLOSSARY}

$\mathbf{I g}=$ immunoglobulin; $\mathbf{M M F}=$ mycophenolate mofetil; $\mathbf{M P A}=$ mycophenolic acid; $\mathbf{M S}=$ multiple sclerosis; $\mathbf{T E}=$ toxoplasmic encephalitis; TMP-SMX = trimethoprim/sulfamethoxazole; $\mathbf{W B C}=$ white blood cell.

Mycophenolate mofetil (MMF) is increasingly used in the treatment of neuromuscular autoimmune diseases such as myasthenia gravis. Toxoplasma gondii encephalitis occurs most often in AIDS patients and posttransplantation and rarely is reported as a complication of immunosuppressive treatment of autoimmune disease. No previous cases of toxoplasmic encephalitis (TE) occurring in association with MMF in the treatment of neuromuscular autoimmune disease have been reported. We report 2 cases of TE associated with immunosuppressive treatment of neuromuscular disease with long-term MMF therapy.

METHODS This article describes 2 patients with neuromuscular disorders on immunotherapy with long-term MMF who developed TE.

RESULTS Case 1. A 77-year-old man with well-controlled myasthenia gravis (positive acetylcholine receptorbinding and -modulating antibodies) on pyridostigmine, prednisone $20 \mathrm{mg}$ qod, and MMF 1,500 mg/day for 3 years presented with a 1-month history of progressive weakness of his right arm and leg, speech difficulty, gait difficulty, and cognitive impairment. Examination was notable for expressive aphasia, right-sided hemiparesis, and right-sided hyperreflexia. MRI brain showed multiple rim-enhancing lesions (figures 1 and 2). CT of the chest, abdomen, and pelvis was unremarkable. Laboratory tests showed normal leukocyte count. CSF analysis showed elevated protein at $64 \mathrm{mg} / \mathrm{dL}$ (normal $15-45 \mathrm{mg} / \mathrm{dL}$ ), 1 white blood cell (WBC) $/ \mathrm{mm}^{3}$, and normal glucose. CSF $T$ gondii B1 gene real-time PCR was positive. T gondii immunoglobulin (Ig) G and IgM serum antibodies were positive. CD4 count was 789 cells $/ \mathrm{mm}^{3}$ (normal 510-2,320 cells $/ \mathrm{mm}^{3}$ ). Serum HIV test was negative. CSF showed scattered, mature-appearing lymphocytes. CSF Gram stain was unremarkable. CSF

From the Department of Neurology, University of North Carolina School of Medicine, Chapel Hill.

Go to Neurology.org/nn for full disclosures. Funding information and disclosures deemed relevant by the authors, if any, are provided at the end of the article. The Article Processing Charge was paid by the authors.

This is an open access article distributed under the terms of the Creative Commons Attribution-Noncommercial No Derivative 3.0 License, which permits downloading and sharing the work provided it is properly cited. The work cannot be changed in any way or used commercially. 
Figure 1 Pre- and posttreatment contrast-enhanced MRI of toxoplasmosis lesion in case 1

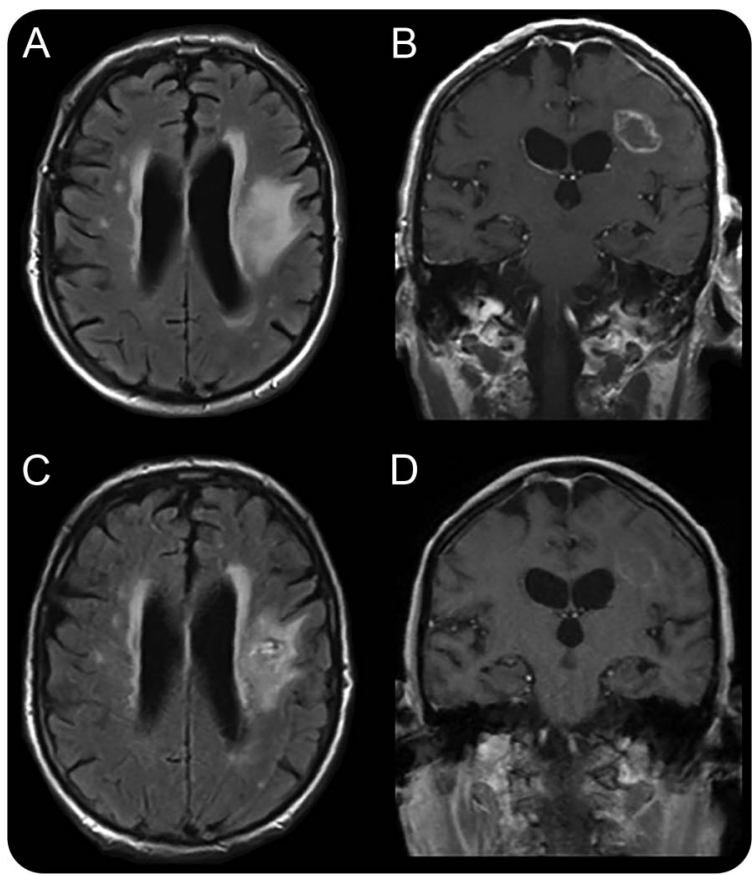

(A, B) Contrast-enhanced MRI demonstrated a 2.3 by $1.3 \mathrm{~cm}$ ring-enhancing lesion in the deep white matter of the left frontoparietal lobe. (C, D) Repeat imaging 1 month later after receiving antitoxoplasmosis treatment. $\mathrm{A}$ and $\mathrm{C}$ are $\mathrm{MRI}$ brain fluid-attenuated inversion recovery sequences. $B$ and $D$ are MRI brain $T 1$ postgadolinium images.

acid-fast bacilli smear and culture were negative. CSF bacterial and fungal culture was negative. CSF histoplasmosis and cryptococcus serologies were negative. Absolute $\mathrm{CD}^{+}$lymphocyte count was low at 751 cells $/ \mu \mathrm{L}$ (normal $915-3,400$ cells $/ \mu \mathrm{L}$ ). Absolute $\mathrm{CD}^{+}$lymphocyte count was low at 400 cells $/ \mu \mathrm{L}$ (normal $510-2,320$ cells $/ \mu \mathrm{L}$ ). Absolute $\mathrm{CD}^{+}$lymphocyte count was normal. MMF was discontinued and he was treated with pyrimethamine $50 \mathrm{mg}$ daily, sulfadiazine $1,000 \mathrm{mg} 4$ times per day,

Figure 2 Pre- and posttreatment contrast-enhanced MRI of second toxoplasmosis lesion in case 1

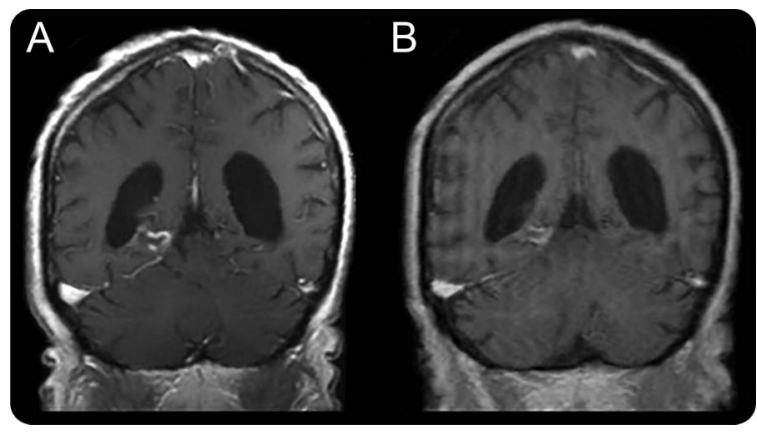

(A) Contrast-enhanced MRI demonstrated a second ring-enhancing lesion in the medial right temporal lobe. (B) Repeat imaging 1 month after receiving antitoxoplasmosis treatment. and leucovorin $25 \mathrm{mg}$ daily for 2 months without significant improvement. He died 2 months after the onset of his symptoms.

Case 2. A 72-year-old woman with a history of inflammatory myopathy presented with fever, confusion, and generalized weakness. Diagnosis of inflammatory myopathy had been made 3 years prior after EMG and muscle biopsy. She had been treated with MMF 1,500 mg twice a day and prednisone $10 \mathrm{mg}$ once a day for 2.5 years. She had received 2 doses of rituximab 1,000 mg 2 weeks apart 8 months prior to presentation. Her examination revealed proximal muscle weakness and encephalopathy. Brain MRI demonstrated multiple ring-enhancing lesions with surrounding vasogenic edema (figure 3). EEG showed no seizures. CT of the chest, abdomen, and pelvis was unremarkable. CSF analysis showed mild lymphocytic pleocytosis (10 WBC/mm $3 \mathrm{~mm}^{3}$, lymphocytes $97 \%$ ) and elevated protein at $124 \mathrm{mg} / \mathrm{dL}$. TE was confirmed by positivity on CSF $T$ gondii B1 gene real-time PCR. Serum $T$ gondii $\operatorname{IgG}$ antibody was positive and serum $T$ gondii IgM antibody was negative. Serum HIV test was negative. The following CSF viral PCR studies were negative: Epstein-Barr virus, human herpesvirus 6, varicella-zoster virus, cytomegalovirus, herpes simplex virus 1 , and herpes simplex virus 2 . CSF Venereal Disease Research Laboratory and CSF cryptococcal antigen were negative. CSF cytopathology demonstrated leukocytosis with mixed lymphocytes and neutrophils. Absolute $\mathrm{CD}^{+}$and $\mathrm{CD}^{+}$ lymphocyte counts were normal at 1,454 and 1,110 cells $/ \mu \mathrm{L}$, respectively (normal 915-3,400 cells $/ \mu \mathrm{L}$ and $510-2,320$ cells $/ \mu \mathrm{L}$, respectively). Absolute $\mathrm{CD} 19^{+}$lymphocyte count was low at 16 cells $/ \mu \mathrm{L}$ (normal 105-920 cells $/ \mu \mathrm{L}$ ), CD19 ${ }^{+}$ lymphocyte population was low at $1 \%$, and $\mathrm{CD}^{2} 0^{+}$was less than $1 \%$ of all lymphocytes. Serum IgG was high at $2,393 \mathrm{mg} / \mathrm{dL}$ (normal $600-1,700 \mathrm{mg} / \mathrm{dL}$ ). MMF was discontinued and she was treated with pyrimethamine $50 \mathrm{mg}$ daily, sulfadiazine $1,000 \mathrm{mg} 4$ times per day, and leucovorin $25 \mathrm{mg}$ daily for 2 months without significant improvement. She died 2 months after the onset of her symptoms.

DISCUSSION MMF is a prodrug of mycophenolic acid (MPA) that exerts its immunosuppressive effect by inhibiting purine biosynthesis. ${ }^{1}$ Specifically, MPA suppresses DNA synthesis via a selective, noncompetitive, reversible inhibition of primarily the type II isoform of inosine monophosphate dehydrogenase, an enzyme central to the de novo production of guanosine. This cytostatic effect is relatively specific to lymphocytes, which are more dependent on this pathway than other cell types. 
Figure 3 Contrast-enhanced MRI of toxoplasmosis lesions in case 2

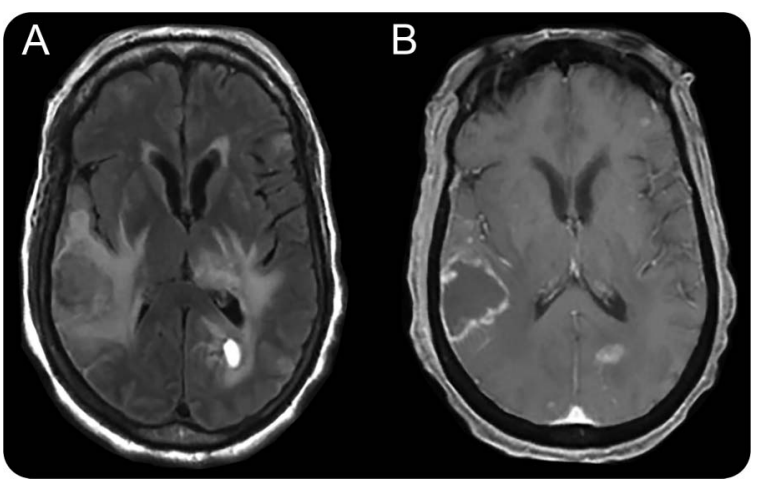

(A) MRI brain fluid-attenuated inversion recovery demonstrated multiple lesions with perilesional edema. (B) Contrast-enhanced MRI brain demonstrated multiple foci of ring-enhancing lesions in the bilateral subcortical regions.

MMF is used in the treatment of several neuroimmunologic diseases, including myasthenia gravis, multiple sclerosis (MS), neuromyelitis optica, chronic inflammatory demyelinating polyneuropathy, multifocal motor neuropathy, and inflammatory myopathy. In most studies, MMF has had an advantageous tolerability and safety profile. ${ }^{2}$ We did not find any prior cases of TE occurring during the treatment of autoimmune neurologic illnesses or rheumatologic illnesses with MMF. In transplant patients, TE has been described in association with different combinations of immunosuppressives used for rejection prophylaxis. For example, TE has been reported in regimens containing cyclosporine, azathioprine, tacrolimus, and methylprednisolone. ${ }^{3-5}$ Toxoplasmosis infections have recently been reported in association with newer biologic immunotherapies in the treatment of autoimmune disease. Infliximab- and adalimumab-associated TE have been reported in the treatment of rheumatoid arthritis. ${ }^{6,7}$ Rituximab-associated TE has been described in the treatment of cryoglobulinemic vasculitis. ${ }^{8}$ Natalizumabassociated toxoplasmic chorioretinitis has been described in the treatment of relapsing-remitting MS. ${ }^{\text {? }}$

In the general US population, the overall seroprevalence of Toxoplasma is $22.5 \% .^{10}$ In regions where Toxoplasma is particularly endemic, such as within Brazil, seroprevalence is as high as $50 \%-70 \% .^{11}$ Immunocompetent patients in the general population with latent toxoplasmosis generally have an asymptomatic natural history. Severe toxoplasmosis infection occurs when chronic $T$ gondii infection is reactivated in the immunocompromised individual. ${ }^{12}$ The predominant manifestation of toxoplasmosis infection in immunosuppressed individuals is TE. Focal findings may include focal seizures, ataxia, hemisensory loss, hemiparesis, and hemiplegia. ${ }^{13}$ Definitive diagnosis of TE requires a consistent clinical presentation, identification of $>1$ consistent lesion on MRI or other brain imaging, and detection of the organism by brain biopsy. PCR has been recommended for diagnosis in immunosuppressed individuals, and it has a high specificity of $96 \%-100 \%$. At present, most clinicians begin treatment for TE following presumptive clinical diagnosis and rely on empiric diagnosis supported by clinical and radiographic improvement in response to antitoxoplasmosis treatment. Brain biopsy is recommended when patients do not respond to toxoplasmosis therapy. ${ }^{13}$ The treatment of choice is a combination of pyrimethamine, sulfadiazine, and leucovorin. Despite treatment, mortality in patients receiving immunosuppression remains high, with reported mortality rates ranging from $40 \%$ to $60 \%$, which is higher than the mortality rate for the AIDS population $(13 \%-31 \%){ }^{14,15}$

The seroprevalence for Toxoplasma in the US region where our cases occurred is relatively low, around $20 \%{ }^{10}$ In our 2 cases, both patients were treated with MMF for more than 2 years prior to onset of neurologic symptoms and diagnosis of TE. Each individual received another immunosuppressive agent in addition to MMF, which may have contributed to the risk of toxoplasmosis infection. In the first case, the patient received low-dose corticosteroids (20 $\mathrm{mg}$ every other day), but there is little evidence to suggest that treatment with low-dose corticosteroids is associated with a significant risk of infection. ${ }^{16} \mathrm{He}$ did have low $\mathrm{CD}^{+}{ }^{+}$and $\mathrm{CD}^{+}{ }^{+} \mathrm{T}$-cell counts consistent with immunosuppression secondary to MMF. In the second case, the patient received rituximab 8 months prior to the development of neurologic symptoms. We could only find one case report of TE occurring in an individual who had received long-term rituximab. ${ }^{8}$ Notably, both of our patients were on MMF $3 \mathrm{~g} /$ day. Studies in the transplant and rheumatology patients have suggested an increased incidence of infectious events with higher MMF dosing. ${ }^{17,18}$ The increased risk of infection should be considered in individuals on high-dose MMF (3 g/day). Despite appropriate treatment, both patients had no significant improvement, which reflects the high morbidity and mortality of TE. As earlier recognition and treatment has been reported to improve outcomes in TE, these case reports emphasize the need to consider TE in any patient receiving MMF who presents with new cognitive or neurologic defects.

The use of trimethoprim/sulfamethoxazole (TMP-SMX) prophylaxis to prevent life-threatening opportunistic infections in individuals receiving immunosuppression for treatment of autoimmune disease has previously been recommended for higher-risk individuals. ${ }^{19,20}$ We recommend that MMF dose not exceed 2-2.5 g/day. If an MMF dose of $3 \mathrm{~g} /$ day is required, then prophylaxis with TMP-SMX can be 
considered. The utility of screening for and prophylaxis against toxoplasmosis in individuals with neuroimmunologic disorders and other autoimmune disorders who receive immunosuppressive therapy requires future study.

\section{AUTHOR CONTRIBUTIONS}

Danilo R. Bernardo, Jr. contributed to the design, drafting, and revising of the manuscript. Nizar Chahin contributed to the conception, design, and revising of the manuscript.

\section{STUDY FUNDING}

No targeted funding reported.

\section{DISCLOSURE}

The authors report no disclosures. Go to Neurology.org/nn for full disclosures.

Received September 19, 2014. Accepted in final form December 4, 2014.

\section{REFERENCES}

1. Allison AC. Mechanisms of action of mycophenolate mofetil. Lupus 2005;14(suppl 1):s2-s8.

2. Iaccarino L, Rampudda M, Canova M, Della Libera S, Sarzi-Puttinic P, Doria A. Mycophenolate mofetil: what is its place in the treatment of autoimmune rheumatic diseases? Autoimmun Rev 2007;6:190-195.

3. Gallino A, Maggiorini M, Kiowski W, et al. Toxoplasmosis in heart transplant recipients. Eur J Clin Microbiol Infect Dis 1996;15:389-393.

4. Renoult E, Georges E, Biava MF, et al. Toxoplasmosis in kidney transplant recipients: report of six cases and review. Clin Infect Dis 1997;24:625-634.

5. Mele A, Paterson PJ, Prentice HG, Leoni P, Kibbler CC. Toxoplasmosis in bone marrow transplantation: a report of two cases and systematic review of the literature. Bone Marrow Transplant 2002;29:691-698.

6. Young JD, McGwire BS. Infliximab and reactivation of cerebral toxoplasmosis. N Engl J Med 2005;353: 1530-1531.

7. Nardone R, Zuccoli G, Brigo F, Trinka E, Golaszewski S. Cerebral toxoplasmosis following adalimumab treatment in rheumatoid arthritis. Rheumatology 2014;53:284-284.

8. Safa G, Darrieux L. Cerebral toxoplasmosis after rituximab therapy. JAMA Intern Med 2013;173:924-926.
9. Zecca C, Nessi F, Bernasconi E, Gobbi C. Ocular toxoplasmosis during natalizumab treatment. Neurology 2009; 73:1418-1419.

10. Jones JL, Kruszon-Moran D, Wilson M, McQuillan G, Navin T, McAuley JB. Toxoplasma gondii infection in the United States: seroprevalence and risk factors. Am J Epidemiol 2001;154:357-365.

11. Pappas G, Roussos N, Falagas ME. Toxoplasmosis snapshots: global status of Toxoplasma gondii seroprevalence and implications for pregnancy and congenital toxoplasmosis. Int J Parasitol 2009;39:1385-1394.

12. Montoya JG, Liesenfeld O. Toxoplasmosis. Lancet 2004; 363:1965-1976.

13. Kaplan JE, Benson C, Holmes KK, et al. Guidelines for prevention and treatment of opportunistic infections in HIV-infected adults and adolescents: recommendations from CDC, the National Institutes of Health, and the HIV Medicine Association of the Infectious Diseases Society of America. MMWR Recomm Rep 2009;58:1-207; quiz CE1-4.

14. Nissapatorn V, Lee C, Quek KF, Leong CL, Mahmud R, Abdullah KA. Toxoplasmosis in HIV/AIDS patients: a current situation. Jpn J Infect Dis 2004;57:160-165.

15. Martina M-N, Cervera C, Esforzado N, et al. Toxoplasma gondii primary infection in renal transplant recipients. Two case reports and literature review. Transpl Int 2010;24:e6-e12.

16. Ruyssen-Witrand A, Fautrel B, Saraux A, Le-Loët X, Pham T. Infections induced by low-dose corticosteroids in rheumatoid arthritis: a systematic literature review. Joint Bone Spine 2010;77:246-251.

17. Sarmiento JM, Dockrell DH, Schwab TR, Munn SR, Paya CV. Mycophenolate mofetil increases cytomegalovirus invasive organ disease in renal transplant patients. Clin Transplant 2000;14:136-138.

18. Pisoni CN, Sanchez FJ, Karim Y, et al. Mycophenolate mofetil in systemic lupus erythematosus: efficacy and tolerability in 86 patients. J Rheumatol 2005;32:1047-1052.

19. Stamp LK, Hurst M. Is there a role for consensus guidelines for P. jiroveci pneumonia prophylaxis in immunosuppressed patients with rheumatic diseases? J Rheumatol 2010;37:686-688.

20. Ernste FC, Reed AM. Idiopathic inflammatory myopathies: current trends in pathogenesis, clinical features, and up-to-date treatment recommendations. Mayo Clin Proc 2013;88:83-105. 


\section{Neurology \\ Neuroimmunology \& Neuroinflammation}

\section{Toxoplasmic encephalitis during mycophenolate mofetil immunotherapy of neuromuscular disease}

Danilo R. Bernardo, Jr and Nizar Chahin

Neurol Neuroimmunol Neuroinflamm 2015;2;

DOI 10.1212/NXI.0000000000000063

This information is current as of January 22, 2015

\section{Updated Information \& Services}

References

Subspecialty Collections

Permissions \& Licensing

Reprints including high resolution figures, can be found at:

http://nn.neurology.org/content/2/1/e63.full.html

This article cites 20 articles, 2 of which you can access for free at: http://nn.neurology.org/content/2/1/e63.full.html\#\#ref-list-1

This article, along with others on similar topics, appears in the following collection(s):

All Immunology

http://nn.neurology.org//cgi/collection/all_immunology

All Neuromuscular Disease

http://nn.neurology.org//cgi/collection/all_neuromuscular_disease

Encephalitis

http://nn.neurology.org//cgi/collection/encephalitis

Myasthenia

http://nn.neurology.org//cgi/collection/myasthenia

Parasitic infections

http://nn.neurology.org//cgi/collection/parasitic_infections

Information about reproducing this article in parts (figures,tables) or in its entirety can be found online at:

http://nn.neurology.org/misc/about.xhtml\#permissions

Information about ordering reprints can be found online: http://nn.neurology.org/misc/addir.xhtml\#reprintsus

Neurol Neuroimmunol Neuroinflamm is an official journal of the American Academy of Neurology.

Published since April 2014, it is an open-access, online-only, continuous publication journal. Copyright $\odot$ 2015 American Academy of Neurology. All rights reserved. Online ISSN: 2332-7812.

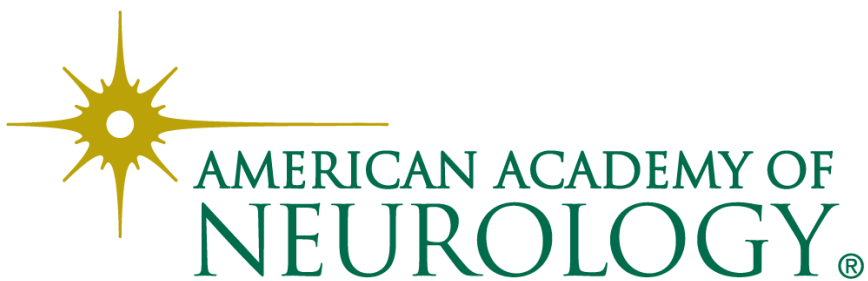

